Archives of Agriculture and Environmental Science

\title{
Heavy metals toxicity of surface soils near industrial vicinity: A study on soil contamination in Bangladesh
}

\author{
Sharmita Rani Mallick ${ }^{1}$, Ram Proshad ${ }^{2,3}$, Md. Saiful Islam ${ }^{4}$, Abu Sayeed ${ }^{5}$, Minhaz Uddin $^{6}$, Jianing \\ $\mathrm{Gao}^{2,3}$ and Dan Zhang ${ }^{2^{*}}$ \\ ${ }^{1}$ Faculty of Agriculture, Patuakhali Science and Technology University, Dumki, Patuakhali - 8602, BANGLADESH \\ ${ }^{2}$ Institute of Mountain Hazards and Environment, Chinese Academy of Sciences, Chengdu - 610041, CHINA \\ ${ }^{3}$ University of Chinese Academy of Sciences, Beijing 100049, CHINA \\ ${ }^{4}$ Department of Applied Biological Chemistry, Graduate School of Agricultural and Life Sciences, University of Tokyo, Tokyo, JAPAN \\ ${ }^{5}$ Department of Post Harvest Technology and Marketing, Patuakhali Science and Technology University, Patuakhali - 8602, \\ BANGLADESH \\ ${ }^{6}$ Department of Environmental Science, Bangladesh Agricultural University, Mymensingh, BANGLADESH \\ *Corresponding author's E-mail: daniezhang@imde.ac.cn
}

\section{ARTICLE HISTORY}

Received: 19 November 2019

Revised received: 04 December 2019

Accepted: 04 December 2019

\section{Keywords}

Heavy metal

Soil contamination

Potential ecological risk

Industrial vicinity

Bangladesh

\section{ABSTRACT}

Tangail district is more vulnerable to heavy metals contamination for industrialization in Bangladesh. Present study describe six heavy metals ( $\mathrm{Cr}, \mathrm{Ni}, \mathrm{Cu}, \mathrm{As}, \mathrm{Cd}$, and $\mathrm{Pb}$ ) in fifteen several sampling locations in industrial vicinity of Tangail district were determined. The concentration of $\mathrm{Cr}, \mathrm{Ni}, \mathrm{Cu}, \mathrm{As}, \mathrm{Cd}$, and $\mathrm{Pb}$ in studied areas soils were observed 0.96-14.04, $0.71-18.39,1.02-34.44,1.2-11.21,0.44-3.31$ and $2.01-28.86 \mathrm{mg} / \mathrm{kg}$, respectively. There is representing a potential risk to the environment for presenting of these heavy metals in soils. This metals are generally toxic to soil and environment. They can persist in the environment for many years and have adverse effect to ecology. Certain indices like contamination factor (CF), enrichment factor (EF), geoaccumulation index (Igeo), pollution load index (PLI), source analysis, principle component analysis (PCA), and toxic units were calculated to determine environmental hazard caused by heavy metals in studied soils. Enrichment factors for the studied metals were in the descending order of $\mathrm{Cd}>\mathrm{As}>\mathrm{Pb}>\mathrm{Cu}>\mathrm{Ni}>\mathrm{Cr}$. The $\mathrm{PLI}$ values for studied metals, causes the $\mathrm{Cd}$ contamination in soil of Tangail district. Potential ecological risk (PER) showed low to very high risk to studied vicinity.

(C)2019 Agriculture and Environmental Science Academy

Citation of this article: Mallick, S.R., Proshad, R., Islam, M.S., Sayeed, A., Uddin, M., Gao, J. and Zhang, D. (2019). Heavy metals toxicity of surface soils near industrial vicinity: A study on soil contamination in Bangladesh. Archives of Agriculture and Environmental Science, 4(4): 356-368, https://dx.doi.org/10.26832/24566632.2019.040401

\section{INTRODUCTION}

Soil, a key element for the survival of human life on the planet, is expected to be the primary recipient of persistent contaminants such as toxic heavy metals (Karim et al., 2014). Heavy metal soil contamination is known to be the most adverse environmental issue in the world. In Bangladesh, due to rapid industrialization, heavy metal contamination from industrial waste is now one of the burning problems. Most industries do not have waste treatment plants and the waste is thrown directly into the open environment such as soil, canal and river. These industrial wastes get mixed to soil and pollute soil. Heavy metals have toxicity, persistent, wide sources, accumulative behaviors and non-biodegradable properties which is the result of great concern at present (Islam et al., 2014a). The toxicity of heavy metals in surface soil can alter the physical, chemical, and biological characteristics of the soil. Because of these increases in heavy metals in the soil, the soil is toxic (Khan et al., 2010; Kumar et al., 2015). Soil pollution by heavy metals is universal issues and anthropogenic activities predispose it (Han et al., 2002; Vare, 2006). In recent decades, soil pollution has occurred due to several heavy metals for further urbanization, industrialization and is more suitable for developing countries because of the indiscriminate development of these industries 
without proper planning (Ahmed et al., 2015). Heavy metals may originate in soils around the industrial area from numerous prime cause but industrial activities is the most important one and also generation of power, manufacturing, burning of fossil fuel and disposal of waste (Karim et al., 2014; Martín et al., 2014). Heavy metals have significant adverse effects on soils because of their potential environmental issues and adverse effects on soil bionetworks (Yuan et al., 2014). To determine environmental risks of toxic elements in soils, several methods have been widely used, like contamination factor, enrichment factor, and geoaccumulation index (Liu et al., 2014; Rashed, 2010). For determination of multiple risk of heavy metals in soil, pollution load index and potential ecological risk index have been used (Huang et al., 2013). Enrichment factor of a vicinity address relative enhancement in any toxic element when pre-industrial soils are compared with studied soils in alike vicinity (Dias et al., 2014). Since soil contamination derives from industry, the present area of study has been given more attention to its pollution in the environment facing threats to heavy metal toxicity contamination resulting from exponential growth, industrial activity and congestion (Islam et al., 2015a). Heavy metals concentration in the industrial area soils were reported in different studies due to rapid industrial activities in Bangladesh. The main purpose of this study was to determine the degree of pollution of toxic elements in soils using enrichment factors, contamination factors, geoaccumulation index, pollution load index, potential ecological hazard, and to identify potential heavy metal sources and soil pollution determination due to ecological threat in Bangladesh's industrial areas.

\section{MATERIALS AND METHODS}

\section{Study areas and sampling}

The samples were collected from Tarutia, Tangail Sadar Upzila of Tangail district, Bangladesh (Figure 1). Tangail district area is $334.26 \mathrm{~km}^{2}$ and situated at the middle part in Bangladesh. Tangail Sadar Upzila is highly densely area in Bangladesh and population density is $1,100 / \mathrm{km}^{2}$ in Tangail district. The study area is situated between Tangail Sadar is located at $24.2500^{\circ} \mathrm{N}$ to $89.9167^{\circ} \mathrm{E}$. Tangail as an industrial vicinity of Bangladesh possess highly vulnerable to environmental pollution now a

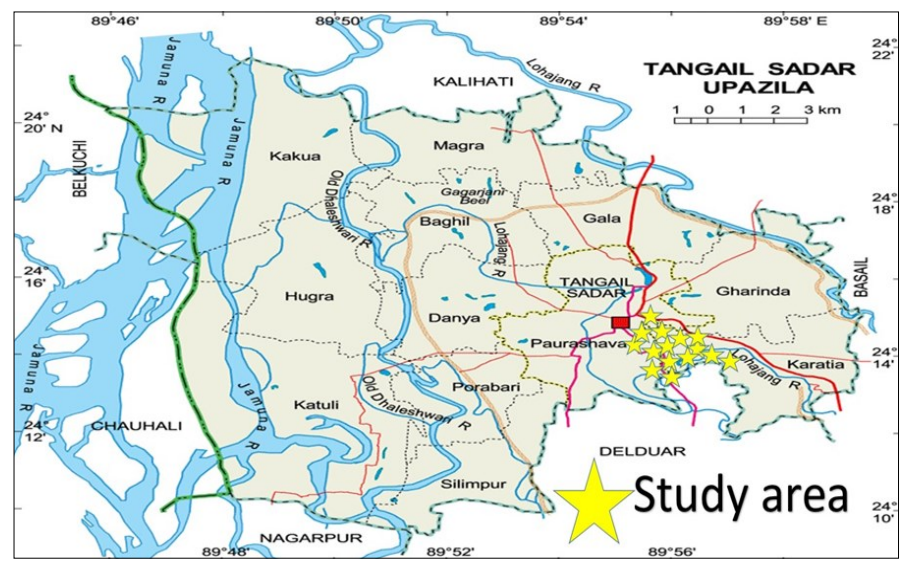

Figure 1. Map showing the study areas of Tangail district, Bangladesh. days. There present different kinds of industries in Tangail district like garments, packaging industry, dyeing, brick kiln, metal work-shops, battery manufacturing industries, tanneries, textile industries, pesticide and fertilizer industries, different food processing industries and other factories produce huge volumes of effluents that contain trace metals. These industries are discharged untreated wastes randomly to river and canals. Then that wastes are mixed with soils and the soil is continuously polluted by toxic elements in the industrial areas of Tangail district in Bangladesh. Soil samples were collected during March - April, 2016. Tarutia was selected for sampling location situated near industrial area of Tangail district, Bangladesh. Fifteen soil sampling sites were selected in the industrial areas of Tangail district. Agricultural field soil samples (samples were collected from surface soil up to $10 \mathrm{~cm}$ ) were taken and three subsamples collected which were used as composite sample by mixing it thoroughly. Soil was taken with the help of a percussion hammer corer (50-80 cm in length) for metal analysis and this samples were treated as preindustrial sample (Schottler and Engstrom, 2006). To crumble all dried soil samples, a porcelain mortar and pestle were used. Then the samples were sieved with $2 \mathrm{~mm}$ nylon sieve. The soil samples were stored in a clean Ziploc bag which was airtight and used for chemical analysis. Several researcher also followed the alike procedure for sampling and storing of soil samples (Oliveira et al., 2012).

\section{Physicochemical parameters analysis}

Soil $\mathrm{pH}$ was determined by using a glass electrode $\mathrm{pH}$ meter (WTW pH 522; Germany). $10 \mathrm{~g}$ of air-dried soil from each sampling site was taken in $50 \mathrm{~mL}$ beakers separately and $25 \mathrm{~mL}$ of distilled water was added to each beaker. The suspension was stirred well for 20 minutes and allowed to stand for about 30 minutes. Then each sample was stirred again for 2 minutes before taking the reading. The position of the electrode was immersed into the partly settled soil suspension and $\mathrm{pH}$ was measured. For EC determination, $5.0 \mathrm{~g}$ of soil was taken in $50 \mathrm{~mL}$ polypropylene tubes and $30 \mathrm{~mL}$ of Milli-Q water was added to the tube. The lid was closed properly and was shaken for $5 \mathrm{~min}$. After that, EC was measured using an EC meter (WTW LF 521; Germany). For organic carbon, $1.0 \mathrm{~g}$ of soil was placed at the bottom of a dry $500 \mathrm{~mL}$ conical flask (Corning/Pyrex). Then 10 $\mathrm{mL}$ of $1 \mathrm{~N} \mathrm{~K}_{2} \mathrm{Cr}_{2} \mathrm{O}_{7}$ was added into the conical flask and swirled a little. The flask was kept on asbestos sheet. Then $20 \mathrm{~mL}$ of concentrated $\mathrm{H}_{2} \mathrm{SO}_{4}$ was added into the conical flask and swirled again 2-3 times. The flask was allowed to stand for 30 minutes and thereafter $200 \mathrm{~mL}$ of distilled water was added. After incorporation of $5.0 \mathrm{~mL}$ of phosphoric acid and 35 drops of diphenylamine indicator, the contents were titrated against ferrous ammonium sulfate solution till the color flashes blue-violet to green. Simultaneously, a blank titration was run without soil. Particle size was determined using the hydrometer method. The textural classes for different soil samples were then determined by plotting the results on a triangular diagram designed by Marshall followed USDA system. The percentage of sand, silt and clay were calculated as follows. 
$\%($ Silt + Clay $)=($ Corrected hydrometer reading at 40 seconds $/$

Oven dry weight of sediment) $\times 100$

$\%($ Clay $)=($ Corrected hydrometer reading after 2 hours $/$ Oven dry weight of sediment) $\times 100$

Sand $(\%)=100-\%$ ( Silt + Clay)

Silt $(\%)=\%($ Silt + Clay $)-\%$ Clay

\section{Heavy metal analysis}

All chemicals were analytical grade reagents; Milli-Q water (Elix UV5 and MilliQ, Millipore, Boston, MA, USA) was used for the preparation of solutions. The Teflon vessel and polypropylene containers were cleaned, soaked in $5 \% \mathrm{HNO}_{3}$ for more than 24 $\mathrm{h}$, then rinsed with Milli-Q water and dried. For metal analysis, 0.3-0.5 g of the soil sample was treated with $6 \mathrm{~mL} 69 \% \mathrm{HNO}_{3}$ (Kanto Chemical Co, Tokyo, Japan) and $2 \mathrm{~mL} 30 \% \mathrm{H}_{2} \mathrm{O}_{2}$ (Wako Chemical Co, Tokyo, Japan) in a closed Teflon vessel and was digested in a Microwave Digestion System (Berghof speedwave, Eningen, Germany). The digested samples were then transferred into a Teflon beaker, and total volume was made up to $50 \mathrm{~mL}$ with Milli-Q water. The digested solution was then filtered by using syringe filter (DISMIC1-25HP PTFE, pore size $=0.45 \mathrm{~mm}$; Toyo Roshi Kaisha, Ltd., Tokyo, Japan) and stored in $50 \mathrm{~mL}$ polypropylene tubes (Nalgene, New York, NY, USA). After that, the digestion tubes were then cleaned using blank digestion procedure following the same procedure of samples. For trace metals, samples were analyzed using inductively coupled plasma mass spectrometer (ICP-MS, Agilent 7700 series, Santa Clara, CA, USA). Instrument operating conditions and parameters for metal analysis are done. The detection limits of ICP-MS for the studied metals were 0.7, 0.6, 0.8, 0.4, 0.06 and $0.09 \mathrm{ng} / \mathrm{L}$ for $\mathrm{Cr}$, $\mathrm{Ni}, \mathrm{Cu}, \mathrm{As}, \mathrm{Cd}$ and $\mathrm{Pb}$, respectively. Multi-element Standard XSTC-13 (Spex CertiPrep $®$, Metuchen, NJ, USA) solutions were used to prepare calibration curves. Multi-element solution (purchased from Agilent Technologies, Japan) was used as tuning solution covering a wide range of masses of elements. All test batches were evaluated using an internal quality approach and validated if they satisfied the defined Internal Quality Controls (IQCs). Before starting the analysis sequence, relative standard deviation (RSD, <5\%) was checked by using the tuning solution purchased from Agilent Technologies. The certified reference materials INCT-CF-3 (corn flour) bought from the National Research Council (Canada), were analyzed to confirm analytical performance and good precision (relative standard deviation below 20\%) of the applied method. Metals in soil samples were analyzed using an inductively coupled plasma mass spectrometer (ICP-MS).

\section{Ecological risk assessment for soil pollution}

Enrichment factor (EF): Enrichment factor (EF) is considered as an effective tool to evaluate the magnitude of contaminants in the environment (Franco-Uría et al., 2009). The EF for each element was calculated to evaluate anthropogenic influences on heavy metals in sediments using the following formula (Selvaraj et al., 2004).
$E F=\left(C_{M} / C_{A l}\right)_{\text {sample }} /\left(C_{M} / C_{A l}\right)_{\text {background }}$

Where, $\left(C_{M} / C_{A l}\right)_{\text {sample }}$ is the ratio of concentration of heavy metal $\left(C_{M}\right)$ to that of aluminum $\left(C_{A l}\right)$ in the soil sample, and $\left(C_{M} / C_{A l}\right)$ background is the same reference ratio in the background sample. Generally, an EF value of about 1 suggests that a given metal may be entirely from crustal materials or natural weathering processes (Zhang and Liu, 2002). Samples having enrichment factor $>1.5$ was considered indicative of human influence and (arbitrarily) an EF of 1.5-3, 3-5, 5-10 and >10 is considered the evidence of minor, moderate, severe, and very severe modification (Birch and Olmos, 2008).

Contamination factor $\left(\mathrm{C}_{\mathrm{f}}^{\mathrm{i}}\right)$ : Contamination factor means the proportion of the heavy metal concentration in the soil to that of baseline or background value.

$C_{f}^{i}=C_{\text {heavy metal }} / C_{\text {background }}$

Contamination factor divided into four classes ranged from 1 to 6 which are: low degree $\left(C_{f}^{i}<1\right)$, moderate degree $\left(1 \leq C_{f}^{i}<3\right)$, considerable degree $\left(3 \leq C_{f}^{i}<6\right)$, and very high degree $\left(C_{f}^{i} \geq 6\right)$ (Islam et al., 2015a). This approach has been used by other researchers e.g. (Proshad et al., 2017; Kumar and Thakur, 2018).

Geoaccumulation index ( $I_{\text {geo }}$ ): Geoaccumulation index (Igeo) is assumed as an impressive tool to determine contamination degree from toxic metals. At present, geoaccumulation index is used globally to assess soil pollution (Bermejo et al., 2003; Kumar and Thakur, 2017). The most effective objective to determine geoaccumulation index (Igeo) is to identify pollution level in soil. Geoaccumulation index (Igeo) may be assessed by applying equation given here by,

$\operatorname{lgeo}=\log 2(\mathrm{Cn} / 1.5 \mathrm{Bn})$

Where, $\mathrm{Cn}$ is the determined element ( $\mathrm{n}$ ) concentration assessed from soil, $\mathrm{Bn}$ is the geochemical baseline value of element $\mathrm{n}$ in background sample (Yu et al., 2008).

Pollution load index: To assess the quality of soil in terms of metal contamination, an integrated approach of pollution load index of the six metals is calculated according to Rashed (Rashed, 2010). The PLI is defined as the $n^{\text {th }}$ root of the multiplications of the contamination factor $\left(C_{f}^{i}\right)$ of metals (Bhuiyan et al., 2011).

$$
P L I=\left(C_{f}{ }^{i} \times C_{f_{2}}^{i} \times C_{f^{3}}^{i} \times \ldots \ldots \times C_{f}{ }^{i}\right)^{1 / n}
$$

The PLI gave an assessment of the overall toxicity status of the sample and also it is a result of the contribution of the six metals. Therefore, PLI value of zero indicates perfection, a value of one indicates the presence of only baseline level of pollutants and values above one would indicate progressive deterioration of the site and estuarine quality (Thomilson et al., 1980). The PLI gave an 
assessment of the overall toxicity status of the sample and also it is a result of the contribution of the six metals.

Potential ecological risk (PER): The degrees of hazardous elements contamination in agricultural soils are determined by PER index. (Guo et al., 2010) and (Yu and Li, 2011) proposed equations which were used to calculate PER and are as follows:

$$
\begin{gathered}
C_{f}^{i}=\frac{C^{i}}{C_{n}^{i}} \quad C_{d}=\sum_{i=1}^{n} C_{f}^{i} \\
E_{r}^{i}=T_{r}^{i} \times C_{f}^{i} \quad \text { PER }=\sum_{i=1}^{m} E_{r}^{i}
\end{gathered}
$$

Where, ${ }^{C_{f}^{i}}$ is the single element contamination factor, $C^{i}$ is the content of the element in samples and $C_{n}^{i}$ is the background value of the element. The background value of $\mathrm{Cr}, \mathrm{Ni}, \mathrm{Cu}, \mathrm{As}, \mathrm{Cd}$ and $\mathrm{Pb}$ in soils were 90, 68, 45, 13, 0.3 and $20 \mathrm{mg} / \mathrm{kg}$, respectively (pre-industrial samples of the study area) (Turekian and Wedepohl, 1961). The sum of $C_{f}^{i}$ for all metals represent the integrated pollution degree ( ${ }^{d}$ ) of the environment. $E_{r}^{i}$ is the potential ecological risk index and $T_{r}^{i}$ is the biological toxic factor of an individual element. The toxic-response factors for $\mathrm{Cr}, \mathrm{Ni}, \mathrm{Cu}, \mathrm{As}, \mathrm{Cd}$ and $\mathrm{Pb}$ were 2, 6, 5, 10, 30 and 5, respectively (Amuno, 2013; Hakanson, 1980; Luo et al., 2007; Wu et al., 2010). PER is the comprehensive potential ecological risk index, which is the sum of $E_{r}^{i}$. Sensitivity of the biological community is represented by it to the toxic substance and indicates the potential ecological risk caused by the overall contamination.

Toxic unit analysis: The calculation of toxic units is considered as severe toxicity of toxic metals in agricultural soils. Toxic unit analysis is the proportion of the assessed concentration of heavy metals in soil to possible effect level (Islam et al., 2014b). When the sum of toxic units for all soil samples is more than 4 , moderate to serious toxicity of heavy metals remain in soil.

\section{Statistical analysis}

SPSS 20.0 (SPSS, USA) was used for statistical analysis for present study. To address the sources of heavy metals in soil, principal component analysis (PCA) were applied. Microsoft Excel 2013 was used for other calculations.

\section{RESULTS AND DISCUSSION}

\section{Physiochemical properties of soil}

Different physical and chemical properties (Texture, pH, EC and organic carbon) of soil were shown in Table 1. Soils $\mathrm{pH}$ values for present study were ranged from 5.48 to 7.15 signifying that the studied soil samples were slightly acidic to neutral except S9 and S13 samples which were alkaline in nature (Table 1). Most of the studied soils were acidic to neutral because of decomposition of organic matter and subsequent formation of carbonic acid (Ahmad et al., 1996). Higher soil acidity favors the availability of cations in soil. Soil pH (acidity) is of particular importance as it controls the behavior of metals and many other soil processes. Heavy metal cations (positively charged metal atoms) are most mobile in acid soils. This means that metal contaminants are more available for uptake by plants, or to move into the water supply (Adeniyi et al., 2008; Oliver, 1997). Electrical conductivity (EC) value of the studied soil was non-saline (0-2 dS/m; SRDI soil salinity class) for all sampling sites which mean the salinity effect is negligible (SRDI, 2009). This condition of soil was due to organic matter decomposition with carbonic acid formation in the studied area soils. The range of organic carbon (\% C) was 0.664 to 3.331. High organic carbon content is an indication that metals are more likely to be bound to organic matter to form metal chelate complexes, and this would also result in less availability of metals to plants (Yap et al., 2009). According to the United States soil texture classification system (NRCS, 1993), the textural analysis revealed that the studied soil samples were loam, sandy loam, and silt loam (Table 1) according to the soil texture classes.

\begin{tabular}{|c|c|c|c|c|c|c|c|}
\hline Sampling sites & $\mathrm{pH}\left(1: 2.5 \mathrm{H}_{2} \mathrm{O}\right)$ & $\mathrm{EC}(\mathrm{dS} / \mathrm{m})$ & Organic carbon (\%) & Sand (\% in $<2 \mathrm{~mm}$ ) & Silt & Clay & Soil type \\
\hline S1 & 6.36 & 0.23 & 1.507 & 49 & 32.5 & 18.5 & Loam \\
\hline S2 & 6.04 & 0.54 & 2.661 & 36 & 51.6 & 12.4 & Silt loam \\
\hline S3 & 5.48 & 0.32 & 0.677 & 46 & 37.5 & 16.5 & Loam \\
\hline S4 & 6.24 & 0.36 & 0.660 & 42.6 & 44.1 & 13.3 & Loam \\
\hline S5 & 6.43 & 0.43 & 1.649 & 47.4 & 37.5 & 15.1 & Loam \\
\hline S6 & 6.87 & 0.21 & 0.996 & 48.5 & 39.1 & 12.4 & Loam \\
\hline S7 & 6.3 & 0.36 & 0.644 & 41.5 & 39.1 & 19.4 & Loam \\
\hline S8 & 6.35 & 0.3 & 0.650 & 60.1 & 26.6 & 13.3 & Sandy loam \\
\hline S9 & 7.11 & 0.22 & 1.019 & 54 & 30 & 16 & Sandy loam \\
\hline S10 & 6.3 & 0.21 & 1.062 & 49 & 34.1 & 16.9 & Loam \\
\hline S11 & 6.7 & 0.32 & 3.331 & 376 & 46.6 & 15.8 & Loam \\
\hline S12 & 6.43 & 0.25 & 0.933 & 51 & 36.6 & 12.4 & Loam \\
\hline S13 & 7.15 & 0.27 & 1.945 & 47.6 & 39.1 & 13.3 & Loam \\
\hline S14 & 6.54 & 0.47 & 1.341 & 53.5 & 35 & 11.5 & Sandy loam \\
\hline S15 & 6.11 & 0.19 & 1.402 & 44 & 36.6 & 19.4 & Loam \\
\hline
\end{tabular}

Table 1. Physiochemical properties of soils collected from industrial areas of Tangail district, Bangladesh

"According to the United states Department of Agriculture soil classification system. 
Heavy metals concentrations in soil

The heavy metals concentrations ( $\mathrm{Cr}, \mathrm{Ni}, \mathrm{Cu}, \mathrm{As}, \mathrm{Cd}$, and $\mathrm{Pb})$ in soil samples were presented in Table 2 . The mean concentrations of $\mathrm{Cr}, \mathrm{Ni}, \mathrm{Cu}, \mathrm{As}, \mathrm{Cd}$, and $\mathrm{Pb}$ in soil were found 4.91, 5.86, $8.06,4.2,1.35$, and $12.11 \mathrm{mg} / \mathrm{kg}$, respectively (Table 3) around the industrial area of Tangail district, Bangladesh. The highest value of $\mathrm{Cr}, \mathrm{Ni}, \mathrm{Cu}, \mathrm{As}, \mathrm{Cd}$ and $\mathrm{Pb}$ were observed in soil collected from S14, S10, S13, S14, and S11 site. Hazardous element concentrations in present study soil samples were compared with other studies. The mean concentration of $\mathrm{Cr}$ was found $4.91 \mathrm{mg} /$ $\mathrm{kg}$ in the present study which was lower than The Dutch Soil Quality Standard (VROM, 2000), Canadian Environmental Quality Guidelines (CCME, 2003) and Australian Guideline for Soil Quality (DEP, 2003) indicating lower contamination of $\mathrm{Cr}$ in soil (Table 2).

Chromium is a toxic heavy metal is discharged from several industries into the agricultural land around industrial areas and pollutes agricultural soils (Nriagu, 1988). Cr concentration was found in the study areas may be disposed of untreated tannery waste to agricultural fields since chromium salt used in tannery industries (Gowd et al., 2010). The concentration of $\mathrm{Cr}$ in agricultural soils varies up to values as high as $350 \mathrm{mg} / \mathrm{kg}$ (Branca et al., 1990). Chromium concentration in the present study was lower than other studies (Ahmad and Goni, 2010; Islam et al., 2014a; Luo et al., 2007; Proshad et al., 2017) conducted different areas in Bangladesh and other countries. The toxicity of $\mathrm{Cr}$ has negative impacts on the growth of plants that interfere with some important metabolic processes (Hasnine et al., 2017; Shanker et al., 2009).

The solubility of nickel in soils increases with its acidity and if the acidity increases it results higher $\mathrm{Ni}$ in soils (Barałkiewicz and Siepak, 1999). In the present study Ni concentrations ranged between $0.71-18.39 \mathrm{mg} / \mathrm{kg}$ in the study area. The highest amount $(18.39 \mathrm{mg} / \mathrm{kg})$ was found in station 10 and the lowest value $(0.71 \mathrm{mg} / \mathrm{kg})$ in station 7 (Table 2). The elevated levels of $\mathrm{Ni}$ were found in station 10 which results from localized additions or accidental spillages of $\mathrm{Ni}$ containing materials (Krishna and Govil, 2007). The mean concentration of $\mathrm{Ni}$ was found $5.86 \mathrm{mg} / \mathrm{kg}$ in the present study which was lower than The Dutch Soil Quality Standard (VROM, 2000), Canadian Environmental Quality Guidelines (CCME, 2003) and Australian Guideline for Soil Quality (DEP, 2003) indicating lower contamination of $\mathrm{Ni}$ in soil (Table 2). Nickel (Ni) concentration in the present study was lower than other studies (Ahmad and Goni, 2010; Islam et al., 2014a; Luo et al., 2007; Proshad et al., 2017) conducted different areas in Bangladesh and other countries.

Table 2. Metal concentration ( $\mathrm{mg} / \mathrm{kg}$ ) in soil collected from industrial areas of Tangail district, Bangladesh.

\begin{tabular}{|c|c|c|c|c|c|c|}
\hline Sampling sites & $\mathrm{Cr}$ & $\mathrm{Ni}$ & $\mathrm{Cu}$ & As & $\mathrm{Cd}$ & $\mathrm{Pb}$ \\
\hline S1 & 0.964 & 8.058 & 8.192 & 2.128 & 0.447 & 12.102 \\
\hline S2 & 2.704 & 5.423 & 5.312 & 2.850 & 2.608 & 2.325 \\
\hline S3 & 4.599 & 3.237 & 2.038 & 1.313 & 0.487 & 11.195 \\
\hline S4 & 1.665 & 2.085 & 2.268 & 3.016 & 0.190 & 2.017 \\
\hline S5 & 0.414 & 3.349 & 6.110 & 2.149 & 0.692 & 12.120 \\
\hline S6 & 5.646 & 2.114 & 9.740 & 1.481 & 0.312 & 6.360 \\
\hline S7 & 5.923 & 0.712 & 4.433 & 1.200 & 0.788 & 9.044 \\
\hline S8 & 2.699 & 1.955 & 2.256 & 1.784 & 1.586 & 4.014 \\
\hline S9 & 4.214 & 3.656 & 1.028 & 1.365 & 1.309 & 17.124 \\
\hline S10 & 4.212 & 18.394 & 2.785 & 5.439 & 1.134 & 13.781 \\
\hline S11 & 5.160 & 8.607 & 7.105 & 3.191 & 0.543 & 28.645 \\
\hline S12 & 4.958 & 3.247 & 5.014 & 10.388 & 2.238 & 26.867 \\
\hline S13 & 10.532 & 9.036 & 34.440 & 8.049 & 2.416 & 13.503 \\
\hline S14 & 5.935 & 11.033 & 18.657 & 11.210 & 3.311 & 17.566 \\
\hline S15 & 14.047 & 7.103 & 11.627 & 7.563 & 2.228 & 5.106 \\
\hline Mean & 4.91 & 5.86 & 8.06 & 4.20 & 1.35 & 12.11 \\
\hline Dutch standard $^{\mathrm{a}}$ & 100 & 35 & 36 & 29 & 0.80 & 85 \\
\hline Canadian guidelines $^{b}$ & 64 & 50 & 63 & 12 & 1.4 & 70 \\
\hline Australian guidelines ${ }^{c}$ & 50 & 60 & 60 & 20 & 3.0 & 300 \\
\hline Background value in Tangail district & 29 & 32 & 27 & 6.5 & 0.82 & 23 \\
\hline
\end{tabular}

${ }^{a}$ (VROM, 2000) ${ }^{b}(C C M E, 2003){ }^{c}(D E P, 2003)$ 
Excessive Cu concentrations are harmful to plants and highly toxic to some microorganisms (Hasnine et al., 2017). Soluble soil Cu can be toxic to plants since Cu-enriched liquid dairy waste used in agricultural land as irrigation water (White and Brown, 2010). In the present study, the value of $\mathrm{Cu}$ ranged between 1.02 to $34.44 \mathrm{mg} / \mathrm{kg}$ (Table 2). The mean concentration of $\mathrm{Cu}$ was found $8.06 \mathrm{mg} / \mathrm{kg}$ in the present study which was lower than The Dutch Soil Quality Standard (VROM, 2000), Canadian Environmental Quality Guidelines (CCME, 2003) and Australian Guideline for Soil Quality (DEP, 2003) indicating lower contamination of $\mathrm{Cu}$ in soil (Table 2). (Alloway, 1990) provided with the regulatory standard for $\mathrm{Cu}$ in soil is $20-30 \mathrm{mg} / \mathrm{kg}$. Cu concentration in the present study was compared to other studies conducted in Bangladesh and other countries. Present studied $\mathrm{Cu}$ concentrations were lower than other studies (Ahmad and Goni, 2010; Islam et al., 2014a; Luo et al., 2007; Proshad et al., 2017).

In the present study, the concentration of As varied between 1.2 to $11.21 \mathrm{mg} / \mathrm{kg}$ (Table 2). A huge amount of groundwater containing As (Hug et al., 2011) is being used for tanning in relation to some chemicals especially arsenic sulfide (Bhuiyan et al., 2011). Moreover, emission and waste from brick fields and incineration activities might contribute to the high concentration of As (Olawoyin et al., 2012). Arsenic in agricultural soils can be derived from both natural and anthropogenic sources, especially use of groundwater for irrigation and uncontrolled application of As enriched fertilizers and pesticides (Neumann et al., 2010). All the concentrations of As found to below the recommended value set by Dutch Soil Quality Standard (VROM, 2000), Canadian Environmental Quality Guidelines (CCME, 2003) and Australian Guideline for Soil Quality (DEP, 2003) (Table 2). As contaminated water and As-enriched fertilizers as well as pesticides were used for irrigation in the agricultural land ((Polizzotto et al., 2013). Moreover, emission and waste from brick fields and incineration activities might contribute to the high concentration of As in agricultural soil (Olawoyin et al., 2012).

Cadmium concentrations were found between 0.44 to $3.31 \mathrm{mg} /$ $\mathrm{kg}$. The mean concentration of Cd was found $1.35 \mathrm{mg} / \mathrm{kg}$ in the present study which was higher than The Dutch Soil Quality Standard (VROM, 2000) but higher than Canadian Environmental Quality Guidelines (CCME, 2003) and Australian Guideline for Soil Quality (DEP, 2003). Cadmium (Cd) concentration in the present study was compared to other studies conducted in Bangladesh and other countries. Present studied Cd concentrations were lower than other studies (Ahmad and Goni, 2010; Islam et al., 2014a; Proshad et al., 2017).

This level of $\mathrm{Pb}$ concentration present in soil due to metal processing factories release $\mathrm{Pb}$ into the open environment and several anthropogenic factors (Nziguheba and Smolders, 2008). In the present study, station 11 showed the elevated concentrations of $\mathrm{Pb}$ which can be due to the emission of $\mathrm{Pb}$ contaminated waste from these sites (Gowd et al., 2010). The mean concentration of $\mathrm{Pb}$ was found $12.11 \mathrm{mg} / \mathrm{kg}$ in the present study which was lower than The Dutch Soil Quality Standard (VROM, 2000), Canadian Environmental Quality Guidelines (CCME, 2003) and

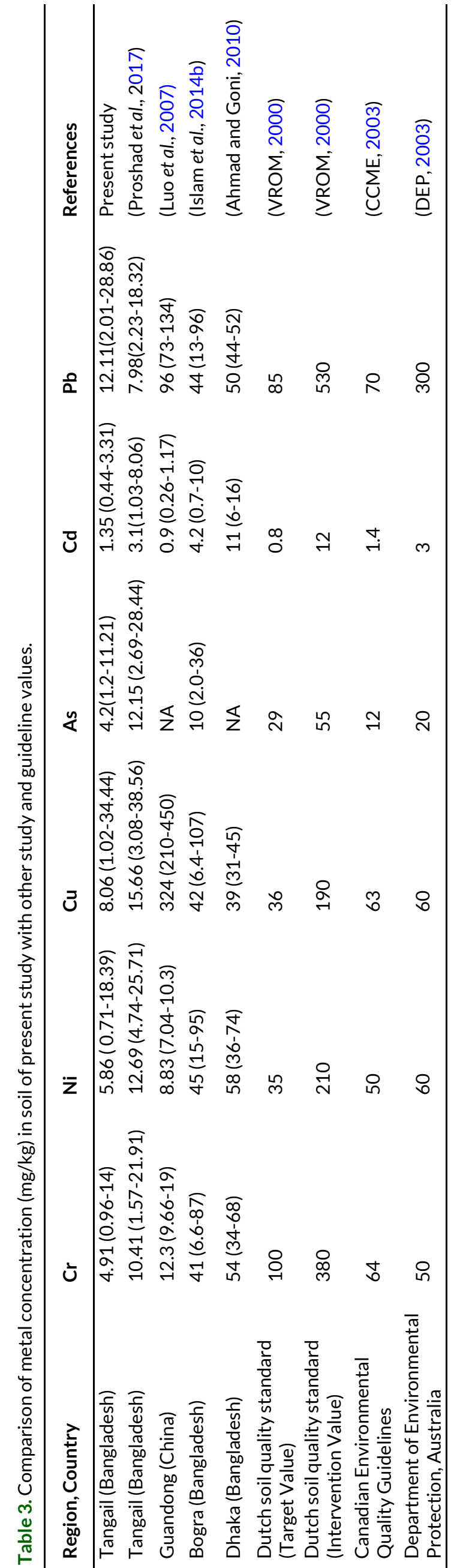


Australian Guideline for Soil Quality (DEP, 2003) indicating lower contamination of $\mathrm{Pb}$ in soil (Table 2). Lead $(\mathrm{Pb})$ concentration in the present study was lower than other studies (Ahmad and Goni, 2010; Islam et al., 2014a; Luo et al., 2007) conducted different areas in Bangladesh and other countries.

\section{Source analysis of heavy metals in soil}

Statistical analyses were performed to elucidate the associations among heavy metals in soils and to identify the important factors involved in controlling the transport and distribution of metal contaminants (Proshad et al., 2019). Pearson's correlation (PC) matrix for analyzed soils parameters was calculated to see if some of the parameters interrelated with each other and the results are presented in Table 4. The value of EC showed significant positive correlation with silt $\left(r=-0.524^{*}\right)$. Sand showed significant positive correlation with organic matter $\left(r=-0.675^{* *}\right)$. There were also showed others positive correlations like silt with organic carbon $\left(r=0.61^{*}\right)$ and $\mathrm{Pb}$ $\left(r=0.59^{*}\right), \mathrm{Cr}$ with $\mathrm{Cu}\left(r=0.575^{*}\right)$, Cu with As $\left(r=0.566^{*}\right)$ and As with $\mathrm{Cd}\left(r=0.762^{* *}\right)$. Considering the relationship between the combinations showed positive significant relationship which indicates the parameters were interrelated with each other and may be originated from the same source to the study area. Other relationships among the constituents of soil were not significant.

Table 4. Correlation coefficient matrix for physiochemical properties of soils and heavy metals collected from industrial areas of Tangail district, Bangladesh.

\begin{tabular}{|c|c|c|c|c|c|c|c|c|c|c|c|c|}
\hline & $\mathrm{pH}$ & EC & Sand & Silt & Clay & $\begin{array}{l}\text { Organic } \\
\text { carbon }\end{array}$ & $\mathrm{Cr}$ & $\mathrm{Ni}$ & $\mathrm{Cu}$ & As & $C d$ & $\mathrm{~Pb}$ \\
\hline $\mathrm{pH}$ & 1 & & & & & & & & & & & \\
\hline EC & -0.277 & 1 & & & & & & & & & & \\
\hline Sand & 0.204 & -0.004 & 1 & & & & & & & & & \\
\hline Silt & -0.163 & $0.524^{*}$ & 0.334 & 1 & & & & & & & & \\
\hline Clay & -0.271 & -0.405 & 0.060 & -0.198 & 1 & & & & & & & \\
\hline $\begin{array}{l}\text { Organic } \\
\text { carbon }\end{array}$ & 0.216 & 0.318 & $0.675^{* *}$ & $0.61^{*}$ & -0.090 & 1 & & & & & & \\
\hline $\mathrm{Cr}$ & 0.160 & -0.373 & 0.013 & 0.007 & 0.212 & 0.074 & 1 & & & & & \\
\hline $\mathrm{Ni}$ & 0.096 & -0.141 & 0.168 & -0.053 & 0.100 & 0.327 & 0.196 & 1 & & & & \\
\hline $\mathrm{Cu}$ & 0.475 & 0.002 & -0.030 & 0.079 & -0.244 & 0.306 & $0.575^{*}$ & 0.315 & 1 & & & \\
\hline As & 0.154 & -0.004 & -0.071 & -0.038 & -0.326 & 0.085 & 0.505 & 0.462 & $0.566^{*}$ & 1 & & \\
\hline $\mathrm{Cd}$ & 0.119 & 0.291 & -0.220 & -0.019 & -0.386 & 0.191 & 0.450 & 0.297 & 0.505 & $0.762^{* *}$ & 1 & \\
\hline $\mathrm{Pb}$ & 0.349 & -0.165 & $0.590^{*}$ & -0.059 & -0.043 & 0.336 & 0.037 & 0.295 & 0.107 & 0.398 & 0.101 & 1 \\
\hline
\end{tabular}

${ }^{*}=$ Correlation is significant at the 0.05 level (two-tailed) ${ }^{* *}=$ Correlation is significant at the 0.01 level (two-tailed)

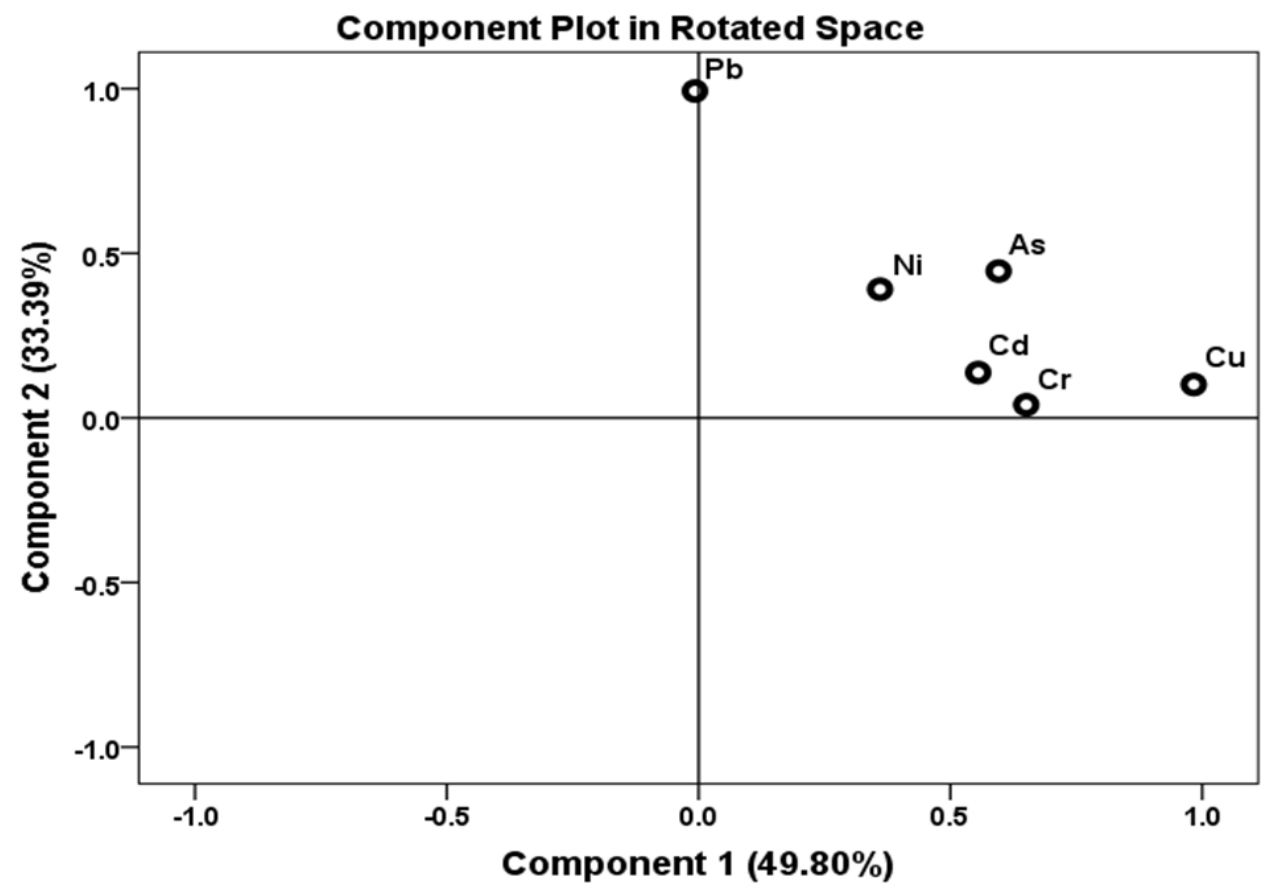

Figure 2. Principal component analysis (PCA) of heavy metals in soil collected from Tangail district, Bangladesh. Considering the highest component loading, first PC exhibited elevated loadings of $\mathrm{Cr}, \mathrm{Ni}, \mathrm{Cu}, \mathrm{As}$ and $\mathrm{Cd}$. Second $\mathrm{PC}$ exhibited elevated loadings of $\mathrm{Pb}$. 
Source of toxic elements in soils were assessed in the form of Principal component analysis (PCA) in different soil sampling sites of Tangail district. Principal component analysis is determined for sources identification (Anju and Banerjee, 2012). The principal component analysis was performed on the tabular and standardized forms of data set and is presented in Table 5 and Figure 2. The extraction method was performed to find out the principal components (PC) in PCA analysis that was Eigen values. In this study, two PCs were computed and the variances explained by them were $49.80 \%$ and $33.39 \%$ for soil samples in the study area (Figure 2). Overall, the PCA revealed two major groups of the metals in soils, where one group consisted of $\mathrm{Cr}, \mathrm{Ni}, \mathrm{Cu}, \mathrm{As}$ and $\mathrm{Cd}$ which were predominantly contributed by anthropogenic activities (Iqbal and Shah, 2011).
Second group consisted of $\mathrm{Pb}$ which were contributed by lithogenic sources or by industrial emissions in the sampling sites (Proshad et al., 2019).

In addition, cluster analysis (CA) with dendrogram using Ward's Method was applied to classify the heavy metals into several groups using the overall heavy metals concentration in soil samples (Figure 3). Several cluster shape were found between heavy metals which were in same cluster were of resembling in nature. In respect of metal pollution in soils exhibited strong significant correlations by building primary clusters with each other (Figure 3). The primary clusters such as $\mathrm{Cr}, \mathrm{As}, \mathrm{Cd}$ and $\mathrm{Ni}$ was formed and another cluster were formed with $\mathrm{Cu}$ and $\mathrm{Pb}$ within a distance of five on the scale (Figure 3).

Table 5. Total variance explained and component matrices for the hazardous elements in surface soils collected from industrial areas of Tangail district, Bangladesh.

\begin{tabular}{|c|c|c|c|c|c|c|c|c|c|c|}
\hline \multicolumn{5}{|c|}{ Initial Eigenvalues } & \multicolumn{3}{|c|}{ Extraction Sums of Squared Loadings } & \multicolumn{3}{|c|}{ Rotation Sums of Squared Loadings } \\
\hline Component & Total & $\begin{array}{c}\begin{array}{c}\% \text { of } \\
\text { variance }\end{array} \\
\end{array}$ & \multicolumn{2}{|c|}{ Cumulative \% } & Total & $\begin{array}{c}\text { \% of } \\
\text { variance }\end{array}$ & Cumulative \% & Total & $\begin{array}{c}\% \text { of } \\
\text { variance }\end{array}$ & $\begin{array}{c}\text { Cumulative } \\
\%\end{array}$ \\
\hline 1 & 92.613 & 49.802 & \multicolumn{2}{|c|}{49.802} & 92.613 & 49.802 & 49.802 & 84.396 & 45.383 & 45.383 \\
\hline 2 & 62.099 & 33.393 & \multicolumn{2}{|c|}{83.195} & 62.099 & 33.393 & 83.195 & 70.316 & 37.812 & 83.195 \\
\hline 3 & 17.271 & 9.287 & \multicolumn{2}{|c|}{92.482} & & & & & & \\
\hline 4 & 8.844 & 4.756 & \multicolumn{2}{|c|}{97.238} & & & & & & \\
\hline 5 & 4.801 & 2.582 & \multicolumn{2}{|c|}{99.820} & & & & & & \\
\hline 6 & 0.335 & 0.180 & \multicolumn{2}{|c|}{100.000} & & & & & & \\
\hline Elements & \multicolumn{4}{|c|}{ Component matrix } & & \multicolumn{5}{|c|}{ Rotated Component Matrix } \\
\hline & \multicolumn{2}{|c|}{ Raw component } & \multicolumn{2}{|c|}{$\begin{array}{c}\text { Rascaled } \\
\text { component }\end{array}$} & & \multicolumn{2}{|c|}{ Raw component } & \multicolumn{3}{|c|}{ Rascaled component } \\
\hline $\begin{array}{l}\text { Component } \\
\text { matrix }\end{array}$ & PC1 & PC2 & PC1 & PC2 & & PC1 & PC2 & PC1 & & PC2 \\
\hline $\mathrm{Cr}$ & 2.039 & -1.073 & 0.577 & -0.304 & & 2.300 & & 0.651 & & \\
\hline $\mathrm{Ni}$ & 2.376 & & 0.511 & & & 1.676 & 1.818 & 0.360 & & 0.391 \\
\hline $\mathrm{Cu}$ & 7.695 & -3.650 & 0.893 & -0.424 & & 8.472 & & 0.983 & & \\
\hline As & 2.554 & & 0.741 & & & 2.054 & 1.538 & 0.596 & & 0.446 \\
\hline $\mathrm{Cd}$ & 0.539 & & 0.546 & & & 0.548 & & 0.555 & & \\
\hline $\mathrm{Pb}$ & 4.097 & 6.860 & 0.509 & 0.853 & & & 7.990 & & & 0.993 \\
\hline
\end{tabular}

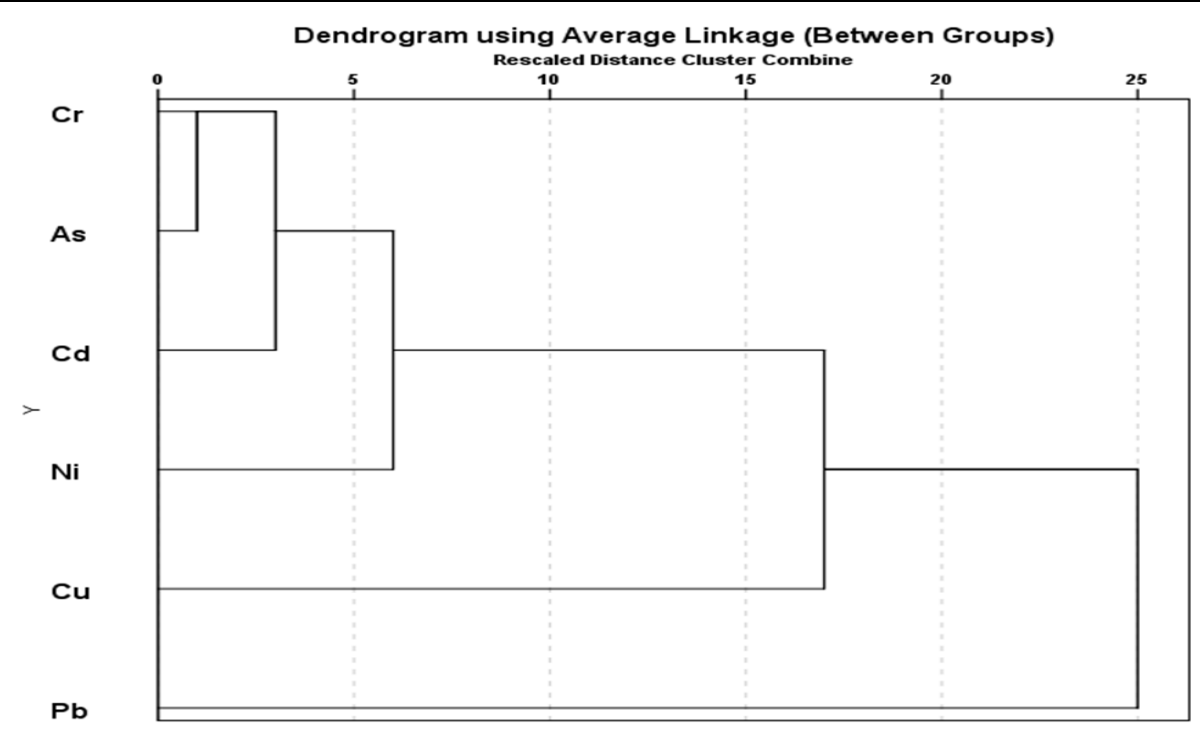

Figure 3. Cluster analysis of soil samples for heavy metals collected from industrial areas of Tangail district, Bangladesh. 


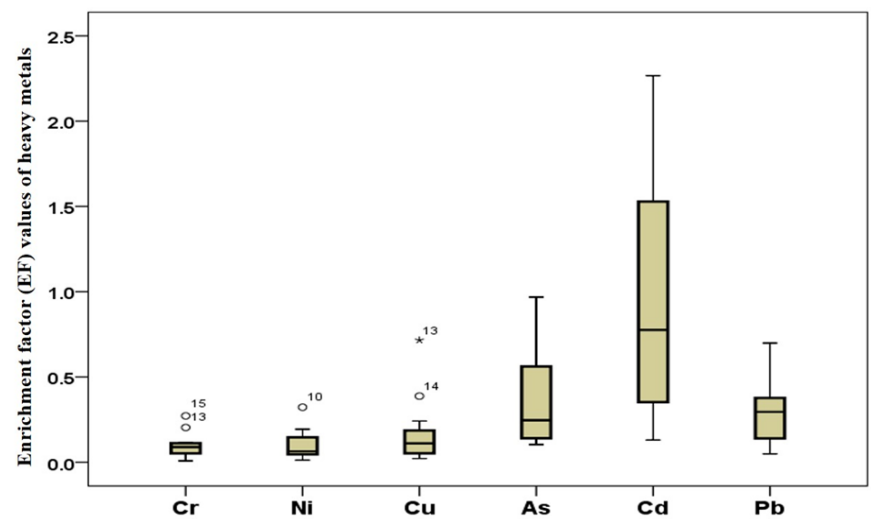

Figure 4. Enrichment factor (EF) values for heavy metals in soils of sampling sites in Tangail district.

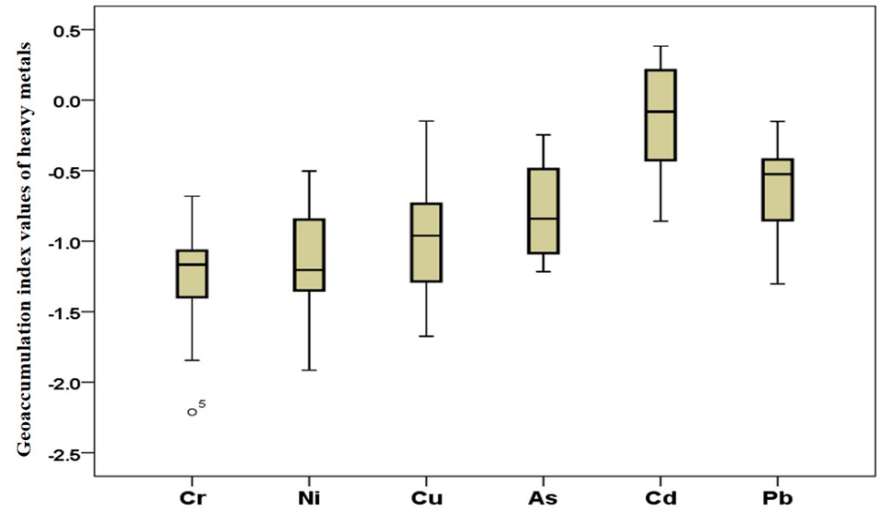

Figure 6. Geo accumulation index (Igeo) value of heavy metals in soils of industrial areas in Tangail district, Bangladesh.

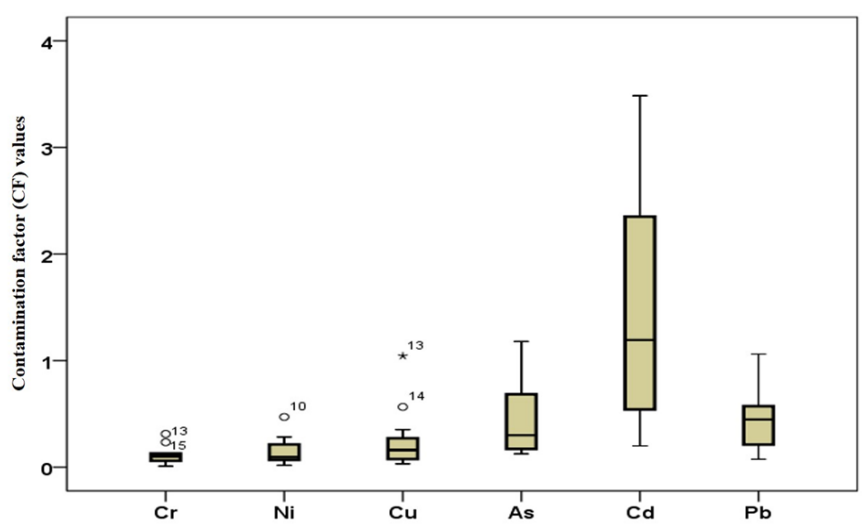

Figure 5. Contamination Factor (CF) of heavy metals in soils collected from industrial areas of Tangail district, Bangladesh.

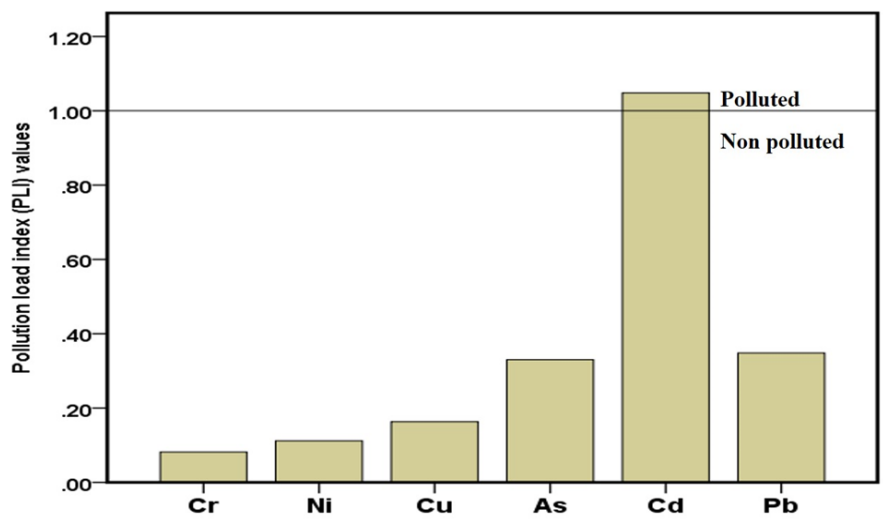

Figure 7. Pollution load index (PLI) value of heavy metals in soils of Tangail district, Bangladesh.

Table 6. Potential ecological risk factor, risk index and pollution degree of heavy metals in soils collected from industrial areas of Tangail district, Bangladesh.

\begin{tabular}{|c|c|c|c|c|c|c|c|c|}
\hline \multirow{2}{*}{ Sites } & \multicolumn{6}{|c|}{$\begin{array}{c}\text { Potential } \\
\text { ecological risk factor }\left(E_{r}^{i}\right) \\
\end{array}$} & \multirow{2}{*}{$\begin{array}{l}\text { Potential } \\
\text { Risk } \\
\text { (PER) }\end{array}$} & \multirow{2}{*}{$\begin{array}{l}\text { Pollution } \\
\text { degree }\end{array}$} \\
\hline & $\mathrm{Cr}$ & $\mathrm{Ni}$ & $\mathrm{Cu}$ & As & $\mathrm{Cd}$ & $\mathrm{Pb}$ & & \\
\hline S1 & 0.171415 & 4.959013 & 4.965106 & 8.961436 & 56.40616 & 8.96466 & 84.42779 & Moderate risk \\
\hline S2 & 0.480704 & 3.33746 & 3.219426 & 11.99998 & 329.3994 & 1.721987 & 350.1589 & Very high risk \\
\hline S3 & 0.817569 & 1.991869 & 1.235273 & 5.527944 & 61.55157 & 8.292594 & 79.41682 & Moderate risk \\
\hline S4 & 0.296072 & 1.283189 & 1.374376 & 12.70005 & 24.04455 & 1.493711 & 41.19196 & Low risk \\
\hline S5 & 0.07364 & 2.061149 & 3.702827 & 9.046509 & 87.4643 & 8.977634 & 111.3261 & Moderate risk \\
\hline S6 & 1.003696 & 1.301099 & 5.902817 & 6.234841 & 39.41723 & 4.711326 & 58.57101 & Low risk \\
\hline S7 & 1.052918 & 0.438321 & 2.686423 & 5.054444 & 99.56221 & 6.699138 & 115.4935 & Moderate risk \\
\hline S8 & 0.47975 & 1.203172 & 1.367192 & 7.512932 & 200.3827 & 2.973274 & 213.919 & Considerable risk \\
\hline S9 & 0.749184 & 2.24997 & 0.623047 & 5.748393 & 165.3143 & 12.6848 & 187.3697 & Considerable risk \\
\hline S10 & 0.748717 & 11.3191 & 1.687635 & 22.89913 & 143.264 & 10.20823 & 190.1268 & Considerable risk \\
\hline S11 & 0.917281 & 5.296747 & 4.305867 & 13.43615 & 68.56799 & 21.21834 & 113.7424 & Moderate risk \\
\hline S12 & 0.881346 & 1.997956 & 3.038928 & 43.73748 & 282.7423 & 19.90128 & 352.2993 & Very high risk \\
\hline S13 & 1.872337 & 5.560771 & 20.87269 & 33.88869 & 305.2379 & 10.0019 & 377.4343 & Very high risk \\
\hline S14 & 1.055059 & 6.789283 & 11.30735 & 47.19896 & 418.2094 & 13.01192 & 497.5719 & Very high risk \\
\hline S15 & 2.497315 & 4.371233 & 7.046637 & 31.84236 & 281.4128 & 3.782345 & 330.9527 & Very high risk \\
\hline
\end{tabular}


Ecological risk assessment

In present experiment, the enrichment factor, contamination factor, geoaccumulation index, and pollution load index (PLI) were used as ecological risk assessment to determine toxic metal pollution in industrial vicinity soils (Table 6 )

The enrichment factor values for the studied soils are presented in Figure 4. Average enrichment factor index of toxic elements assume enrichment of these metals in different sampling locations in the industrial vicinity of Tangail district, Bangladesh. For enrichment factors, cadmium and arsenic have the highest enrichment factor value which indicate soil contamination for total sampling locations. Enrichment factor for studied heavy metals showed a decreasing order of $\mathrm{Cd}>\mathrm{As}>\mathrm{Pb}>\mathrm{Cu}>\mathrm{Ni}>\mathrm{Cr}$ in all sampling locations. Usually, a little enrichment values causes high contribution for crusted source in soils which were identified by several studies where anthropogenic sources have substantial contribution causes high EFs (Islam et al., 2015b; Rashed, 2010).

Four types of contamination Factors (CF), four types of degree of contamination (Cd), five types of Eir and four types of PER were given by Hakanson (Hakanson, 1980) presented in Table 7. The contamination factor (CF) for individual metal were presented in Figure 5. In the studied vicinity, contamination factor was low and was considerable degree only for $\mathrm{Cd}$.

Geoaccumulation index $\left(\mathrm{I}_{\mathrm{geo}}\right)$ values were shown in Figure 6. The $I_{\text {geo }}$ values presented the decreasing order of $\mathrm{Cd}>\mathrm{Pb}>\mathrm{As}>\mathrm{Cu}>\mathrm{Ni}>\mathrm{Cr}$. Average lgeo values for the studied toxic metals for studied locations causing slowly contamination of soil with heavy metals.

Pollution load index (PLI) value is zero means accurate; PLI value is one means there only present baseline level of contaminants where PLI values above 1 means successive contamination by heavy metals in soils (Islam et al., 2015b; Proshad et al., 2017). Present studied soils were polluted by $C d$ and it was observed for others metals that PLI values was less than one for all sampling sites (Figure 7).

PER index of single metal $\left(E_{r}^{i}\right)$ with combining potential ecological risk index of the environment (PER) (Table 6) with classifications of PER (Table 7), studied area soil samples indicate the low to very high risk which must possess ecological hazard in the studied vicinity. For individual metal ecological risk assessment, cadmium showed the highest risk and the studied vicinity soils resulted from moderate, considerable and very high potential ecological risk due to combining toxic metal effects. The order of $E_{r}^{i}$ for studied soil sample followed decreasing order of $\mathrm{Cd}>\mathrm{As}>\mathrm{Pb}>\mathrm{Cu}>\mathrm{Ni}>\mathrm{Cr}$. Cd contributes significantly higher than other metals as potential ecological risk index of the environment (PER) which can be due to the effect from anthropogenic activities such as the application of phosphate fertilizers and industrial activities (Martín et al., 2013).

Sum of toxic units ( $\Sigma T$ TUs) determine as possible heavy metal toxicity in soils (Figure 8). Toxic units may be calculated as the ratio of heavy metal concentration in soil which is measured to probable effect levels (PELs) (Islam et al., 2015a). Total toxic unit 


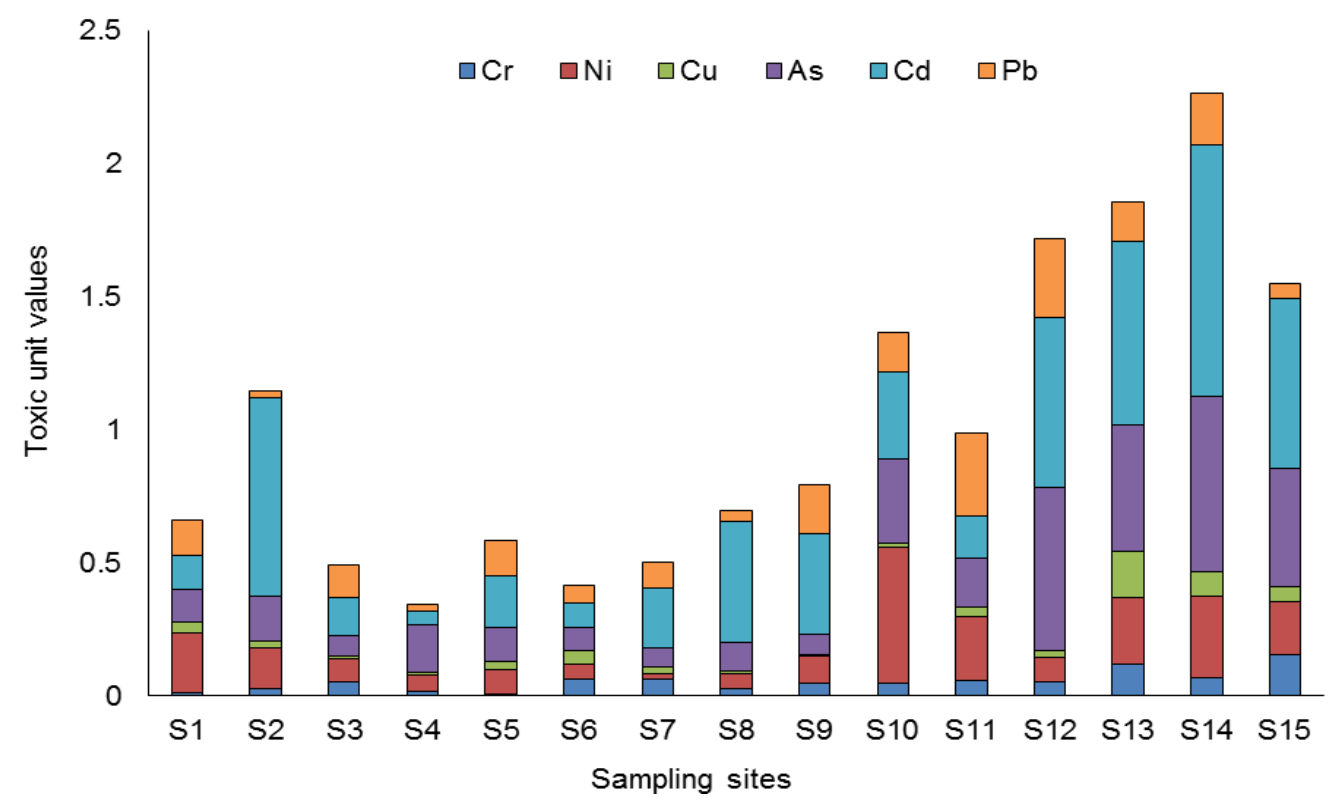

Figure 8. Estimated sum of the toxic unit (TU) in soils of industrial areas of Tangail district, Bangladesh.

( $\Sigma T U s)$ with toxic units (TU) due to heavy metals toxicity in several soil sampling locations in industrial vicinity were presented in Figure 6. Moderate to serious toxicity of hazardous materials were resulted when sum of toxic units of studied soil samples exceed 4 and it causes serious threat to environment. Total toxic units ( $\Sigma$ TUs) for different sampling sites like S12, S13 and S14 were higher than other sites. In the present study, no sample was found which sum of toxic units was higher than 4 .

\section{Conclusion}

Present study indicated that cadmium have the most hazardous effect to soil samples and soils were polluted by Cd (about 70\% soil samples exceed the Dutch soil quality target value). Contamination factors and pollution load index of $\mathrm{Cd}$ was higher than other metals in the studied areas. It was also observed from the study that heavy metal concentration in industrial vicinity soils for Bangladesh varied in different locations. Geogenic with anthropogenic elements are the major reasons for enrichment of toxic metals in soils. Around $66 \%$ samples were polluted according to potential ecological risk (moderate to very high risk). Maximum sampling sites in the industrial vicinity of Tangail district showed cadmium toxicity with severe ecological risk for single toxic element. So in Tangail district, ecological risk indexes for toxic elements were so much high. There is urgent need to study again in present studied area and to increase public awareness not to throw industrial wastages in the open environment.

\section{ACKNOWLEDGMENTS}

The authors thank the authority of Patuakhali Science and Technology University (PSTU), Bangladesh for providing laboratory facilities to complete this study.

\section{Conflict of interest}

No any conflict of interest was declared by the authors.
Open Access: This is an open access article distributed under the terms of the Creative Commons Attribution 4.0 License, which permits unrestricted use, distribution, and reproduction in any medium, provided the original author(s) if the sources are credited.

\section{REFERENCES}

Adeniyi, A.A., Yusuf, K.A. and Okedeyi, O.O. (2008). Assessment of the exposure of two fish species to metals pollution in the Ogun river catchments, Ketu, Lagos, Nigeria. Environmental Monitoring and Assessment, 137: 451-458, https://doi.org/10.1007/s10661-007-9780-5

Ahmad, J.U. and Goni, M.A. (2010). Heavy metal contamination in water, soil, and vegetables of the industrial areas in Dhaka, Bangladesh. Environmental Monitoring and Assessment, 166: 347-357, https://doi.org/10.1007/s10661-009-1006-6

Ahmad, S., Siddiqui, E.N. and Khalid, S. (1996). Studies on certain physico chemical properties of soil of two fresh water ponds of Darbhanga. Environmental Pollution, 31: 31-39.

Ahmed, M.K., Shaheen, N., Islam, M.S., Habibullah-Al-Mamun, M., Islam, S. and Banu, C.P. (2015). Trace elements in two staple cereals (rice and wheat) and associated health risk implications in Bangladesh. Environmental Monitoring and Assessment, 187: 326, https://doi.org/10.1007/s10661-015-4576-5

Alloway, B.J. (1990). Heavy metals in soils. John Willey and Sons. Inc. NY USA 3740, https://scialert.net/abstract/?doi=jas.2004.1.20

Amuno, S.A. (2013). Potential ecological risk of heavy metal distribution in cemetery soils. Water, Air, \& Soil Pollution, 224: 1435, https://doi.org/10.1007/s11270-013-1435-2

Anju, M. and Banerjee, D.K. (2012). Multivariate statistical analysis of heavy metals in soils of a $\mathrm{Pb}-\mathrm{Zn}$ mining area, India. Environmental Monitoring and Assessment, 184: 4191-4206, https://doi.org/10.1007/s10661-011-2255-8

Barałkiewicz, D. and Siepak, J. (1999). Chromium, nickel and cobalt in environmental samples and existing legal norms. Polish Journal of Environmental Studies 8: 201-208.

Bermejo, J.C.S., Beltrán, R. and Ariza, J.L.G. (2003). Spatial variations of heavy metals contamination in sediments from Odiel river (Southwest Spain). Environment International, 29: 69-77, https://doi.org/10.1016/S0160-4120(02)00147-2

Bhuiyan, M.A.H., Suruvi, N.I., Dampare, S.B., Islam, M.A., Quraishi, S.B., Ganyaglo, S. and Suzuki, S. (2011). Investigation of the possible sources of heavy metal contamination in lagoon and canal water in the tannery industrial area in Dhaka, Bangladesh. Environmental Monitoring and Assessment, 175: 633-649, https://doi.org/10.1007/s10661-010-1557-6

Birch, G.F. and Olmos, M.A. (2008). Sediment-bound heavy metals as indicators of human influence and biological risk in coastal water bodies. ICES Journal of Marine Science, 65: 1407-1413, https://doi.org/10.1093/icesjms/fsn139

Branca, M., Micera, G., Kozlowski, H. and Swiatek, J. (1990). Reduction of chromate 
ions by glutathione tripeptide in the presence of sugar ligands. Journal of Inorganic Biochemistry, 39: 217-226, https://doi.org/10.1016/0162-0134(90)84005-A

CCME (Canadian Council of Ministers of the Environment). (2003). Canadian Environmental Quality Guidelines.

DEP (Department of Environmental Protection). (2003). Assessment Levels for Soil, Sediment and Water Contaminated Sites Management Series Perth's, Australia. www.environ.wa.gov.au/.

Dias, C.L., Oliveira, M.L.S., Hower, J.C., Taffarel, S.R., Kautzmann, R.M. and Silva, L.F.O. (2014). Nanominerals and ultrafine particles from coal fires from Santa Catarina, South Brazil. International Journal of Coal Geology, 122: 50-60, https://doi.org/10.1016/j.coal.2013.12.011

Franco-Uría, A., López-Mateo, C., Roca, E. and Fernández-Marcos, M.L. (2009). Source identification of heavy metals in pastureland by multivariate analysis in NW Spain. Journal of Hazardous Materials, 165: 1008-1015, https://doi.org/10.1016/j.jhazmat.2008.10.118

Gowd, S.S., Reddy, M.R. and Govil, P.K. (2010). Assessment of heavy metal contamination in soils at Jajmau (Kanpur) and Unnao industrial areas of the Ganga Plain, Uttar Pradesh, India. Journal of Hazardous Materials, 174: 113-121, https://doi.org/10.1016/j.jhazmat.2009.09.024

Guo, W., Liu, X., Liu, Z. and Li, G. (2010). Pollution and potential ecological risk evaluation of heavy metals in the sediments around Dongjiang Harbor, Tianjin. Procedia Environmental Sciences, 2: 729-736, https://doi.org/10.1016/j.proenv.2010.10.084

Hakanson, L. (1980). An ecological risk index for aquatic pollution control. A sedimentological approach. Water Research, 14: 975-1001, https://doi.org/10.1016/0043-1354(80)90143-8

Han, F.X., Banin, A., Su, Y., Monts, D.L., Plodinec, J.M., Kingery, W.L. and Triplett, G.E. (2002). Industrial age anthropogenic inputs of heavy metals into the pedosphere. Naturwissenschaften, 89: 497-504, https://doi.org/10.1007/s00114-002-0373-4

Hasnine, M.T., Huda, M.E., Khatun, R., Saadat, A.H.M., Ahasan, M., Akter, S., Uddin, M.F., Monika, A.N., Rahman, M.A. and Ohiduzzaman, M. (2017). Heavy Metal Contamination in Agricultural Soil at DEPZA, Bangladesh. Environment and Ecology Research, 5: 510-516, http://www.hrpub.org/journals/article_info.php?aid=6427

Huang, L., Pu, X., Pan, J.-F. and Wang, B. (2013). Heavy metal pollution status in surface sediments of Swan Lake lagoon and Rongcheng Bay in the northern Yellow Sea. Chemosphere, 93: 1957-1964, https://doi.org/10.1016/j.chemosphere.2013.06.080

Hug, S.J., Gaertner, D., Roberts, L.C., Schirmer, M., Ruettimann, T., Rosenberg, T.M., Badruzzaman, A.B.M. and Ali, M.A. (2011). Avoiding high concentrations of arsenic, manganese and salinity in deep tubewells in Munshiganj District, Bangladesh. Applied Geochemistry, 26: 1077-1085, https://doi.org/10.1016/j.apgeochem.2011.03.012

Iqbal, J. and Shah, M.H. (2011). Distribution, correlation and risk assessment of selected metals in urban soils from Islamabad, Pakistan. Journal of Hazardous Materials, 192: 887-898, https://doi.org/10.1016/j.jhazmat.2011.05.105

Islam, M.S., Han, S., AHMED, M.K. and Masunaga, S. (2014a). Assessment of trace metal contamination in water and sediment of some rivers in Bangladesh. Journal of Water and Environment Technology, 12: 109-121, https://doi.org/10.2965/jwet.2014.109

Islam, M.S., Ahmed, M.K., Habibullah-Al-Mamun, M. and Masunaga, S. (2014b). Trace metals in soil and vegetables and associated health risk assessment. Environmental Monitoring and Assessment, 186: 8727-8739, https://doi.org/10.1007/s10661-014-4040-y

Islam, M.S., Ahmed, M.K., Habibullah-Al-Mamun, M. and Hoque, M.F. (2015a). Preliminary assessment of heavy metal contamination in surface sediments from a river in Bangladesh. Environmental Earth Sciences, 73: 1837-1848, https://doi.org/10.1007/s12665-014-3538-5

Islam, M.S., Ahmed, M.K., Raknuzzaman, M., Habibullah-Al-Mamun, M. and Islam, M.K. (2015b). Heavy metal pollution in surface water and sediment: a preliminary assessment of an urban river in a developing country. Ecological Indicators, 48: 282-291, https://doi.org/10.1016/j.ecolind.2014.08.016

Karim, Z., Qureshi, B.A., Mumtaz, M. and Qureshi, S. (2014). Heavy metal content in urban soils as an indicator of anthropogenic and natural influences on landscape of Karachi-a multivariate spatio-temporal analysis. Ecological Indicators, 42: 20-31, https://doi.org/10.1016/j.ecolind.2013.07.020

Khan, S., Rehman, S., Khan, A.Z., Khan, M.A. and Shah, M.T. (2010). Soil and vegetables enrichment with heavy metals from geological sources in Gilgit, northern Pakistan. Ecotoxicology and Environmental Safety, 73: 1820-1827, https://doi.org/10.1016/j.ecoenv.2010.08.016
Krishna, A.K. and Govil, P.K. (2007). Soil contamination due to heavy metals from an industrial area of Surat, Gujarat, Western India. Environmental Monitoring and Assessment, 124: 263-275, https://doi.org/10.1007/s10661-006-9224-7

Kumar, V., Chopra, A.K., Kumar, S., Singh, J. and Thakur, R.K. (2015). Effects of pulp and paper mill effluent disposal on soil characteristics in the vicinity of Uttaranchal Pulp and Paper Mill, Haridwar (Uttarakhand), India. International Journal of Agriculture Science and Research 4: 117-125.

Liu, G., Yu, Y., Hou, J., Xue, W., Liu, X., Liu, Y., Wang, W., Alsaedi, A., Hayat, T. and Liu, Z. (2014). An ecological risk assessment of heavy metal pollution of the agricultural ecosystem near a lead-acid battery factory. Ecological Indicators, 47: 210-218, https://doi.org/10.1016/j.ecolind.2014.04.040

Luo, W., Lu, Y., Giesy, J.P., Wang, T., Shi, Y., Wang, G. and Xing, Y. (2007). Effects of land use on concentrations of metals in surface soils and ecological risk around Guanting Reservoir, China. Environmental Geochemistry and Health, 29: 459-471, https://doi.org/10.1007/s10653-007-9115-z

Martín, J.A.R., Ramos-Miras, J.J., Boluda, R. and Gil, C. (2013). Spatial relations of heavy metals in arable and greenhouse soils of a Mediterranean environment region (Spain). Geoderma, 200: 180-188, https://doi.org/10.1016/j.geoderma.2013.02.014

Martín, J.A.R., Gutiérrez, C., Escuer, M., García-González, M.T., Campos-Herrera, R. and Águila, N. (2014). Effect of mine tailing on the spatial variability of soil nematodes from lead pollution in La Union (Spain). Science of the Total Environment, 473: 518-529, https://doi.org/10.1016/j.scitotenv.2013.12.075

Neumann, R.B., Ashfaque, K.N., Badruzzaman, A.B.M., Ali, M.A., Shoemaker, J.K. and Harvey, C.F. (2010). Anthropogenic influences on groundwater arsenic concentrations in Bangladesh. Nature Geoscience, 3: 46, https://doi.org/10.1038/ngeo685

NRCS, U. (1993). Soil survey division staff (1993) soil survey manual. Soil conservation service. US Department of Agriculture Handbook 18: 315.

Nriagu, J.O. (1988). A silent epidemic of environmental metal poisoning? Environmental Pollution, 50: 139-161, https://doi.org/10.1016/0269-7491(88)90189-3

Nziguheba, G. and Smolders, E. (2008). Inputs of trace elements in agricultural soils via phosphate fertilizers in European countries. Science of the Total Environment, 390: 53-57, https://doi.org/10.1016/j.scitotenv.2007.09.031

Olawoyin, R., Oyewole, S.A. and Grayson, R.L. (2012). Potential risk effect from elevated levels of soil heavy metals on human health in the Niger delta. Ecotoxicology and Environmental Safety, 85: 120-130, https://doi.org/10.1016/j.ecoenv.2012.08.004

Oliveira, M.L.S., Ward, C.R., Izquierdo, M., Sampaio, C.H., de Brum, I.A.S., Kautzmann, R.M., Sabedot, S., Querol, X. and Silva, L.F.O. (2012). Chemical composition and minerals in pyrite ash of an abandoned sulphuric acid production plant. Science of the Total Environment, 430: 34-47, https://doi.org/10.1016/j.scitotenv.2012.04.046

Oliver, M.A. (1997). Soil and human health: a review. European Journal of Soil Science, 48: 573-592, https://doi.org/10.1111/j.1365-2389.1997.tb00558.x

Polizzotto, M.L., Lineberger, E.M., Matteson, A.R., Neumann, R.B., Badruzzaman, A.B.M. and Ali, M.A. (2013). Arsenic transport in irrigation water across ricefield soils in Bangladesh. Environmental Pollution, 179: 210-217, https://doi.org/10.1016/j.envpol.2013.04.025

Proshad, R., Ahmed, S., Rahman, M. and Kumar, T. (2017). Apportionment of hazardous elements in agricultural soils around the vicinity of brick kiln in Bangladesh. Journal of Environmental and Analytical Toxicology, 7: 525-2161, https://doi.org/0.4172/2161-0525.1000439

Proshad, R., Kormoker, T. and Islam, S. (2019). Distribution, source identification, ecological and health risks of heavy metals in surface sediments of the Rupsa River, Bangladesh. Toxin Reviews, 1-25, https://doi.org/10.1080/15569543.2018.1564143

Rashed, M.N. (2010). Monitoring of contaminated toxic and heavy metals, from mine tailings through age accumulation, in soil and some wild plants at Southeast Egypt. Journal of Hazardous Materials, 178: 739-746, https://doi.org/10.1016/j.jhazmat.2010.01.147

Schottler, S.P., and Engstrom, D.R. (2006). A chronological assessment of Lake Okeechobee (Florida) sediments using multiple dating markers. Journal of Paleolimnology, 36: 19-36, https://doi.org/10.1007/s10933-006-0007-5

Selvaraj, K., Mohan, V.R. and Szefer, P. (2004). Evaluation of metal contamination in coastal sediments of the Bay of Bengal, India: geochemical and statistical approaches. Marine Pollution Bulletin, 49: 174-185.

Shanker, A.K., Djanaguiraman, M. and Venkateswarlu, B. (2009). Chromium interactions in plants: current status and future strategies. Metallomics, 1: 375-383.

SRDI (2009). Saline Soils of Bangladesh by Soil Resources Development Institute, Dhaka, Bangladesh. 
Thomilson, D.C., Wilson, D.J., Harris, C.R. and Jeffrey, D.W. (1980). Problem in heavy metals in estuaries and the formation of pollution index. Helgol. Wiss. Meeresunlter, 33: 566-575, https://doi.org/10.1007/BF02414780

Turekian, K.K. and Wedepohl, K.H. (1961). Distribution of the elements in some major units of the earth's crust. Geological Society of America Bulletin, 72: 175 -192, https://doi.org/10.1130/0016-7606(1961)72[175:DOTEIS]2.0.CO;2

Vare, L. (2006). Anthropogenic inputs of heavy metals to the Kongsfjord area. In Geophysical Research Abstracts, p. 6079.

VROM (2000). Circular on Target Values and Intervention Values for Soil Remediation. Spatial Planning and Environment, Netherlands, Ministry of Housing, Spatial Planning and Environment.

White, P.J. and Brown, P.H. (2010). Plant nutrition for sustainable development and global health. Annals of Botany, 105: 1073-1080, https://doi.org/10.1093/aob/mcq085

Wu, Y.G., Xu, Y.N., Zhang, J.H. and Hu, S.H. (2010). Evaluation of ecological risk and primary empirical research on heavy metals in polluted soil over Xiaoqinling gold mining region, Shaanxi, China. Transactions of Nonferrous Metals Society of China, 20: 688-694, https://doi.org/10.1016/S1003-6326(09)60199-0

Yap, D.W., Adezrian, J., Khairiah, J., Ismail, B.S. and Ahmad-Mahir, R. (2009). The uptake of heavy metals by paddy plants (Oryza sativa) in Kota Marudu, Sabah, Malaysia. American Eurasian Journal of Agriculture and Environmental Science, 6: 16-19.

$\mathrm{Yu}, \mathrm{S}$. and Li, X. (2011). Distribution, availability, and sources of trace metals in different particle size fractions of urban soils in Hong Kong: implications for assessing the risk to human health. Environmental Pollution, 159: 1317-1326, https://doi.org/10.1016/j.envpol.2011.01.013

Yu, L., Xin, G., Gang, W., ZHANG, Q., Qiong, S.U. and Guoju, X. (2008). Heavy metal contamination and source in arid agricultural soil in central Gansu Province, China. Journal of Environmental Sciences 20: 607-612, https://doi.org/10.1016/S1001-0742(08)62101-4

Yuan, G.L., Sun, T.H., Han, P., Li, J. and Lang, X.X. (2014). Source identification and ecological risk assessment of heavy metals in topsoil using environmental geochemical mapping: typical urban renewal area in Beijing, China. Journal of Geochemical Exploration 136: 40-47, https://doi.org/10.1016/j.gexplo.2013.10.002

Zhang, J. and Liu, C.L. (2002). Riverine composition and estuarine geochemistry of particulate metals in China-weathering features, anthropogenic impact and chemical fluxes. Estuarine, Coastal and Shelf Science, 54: 1051-1070, https://doi.org/10.1006/ecss.2001.0879 